\title{
ZAKAT AND ECONOMIC DEVELOPMENT ANALYSIS OF BANGKA BELITUNG TOWARDS SUSTAINABLE DEVELOPMENT GOALS 2030
}

\author{
Eka Fitriyanti, Aning Kesuma Putri, Devi Valeriani \\ University of Bangka Belitung
}

Email: ekafy1104@gmail.com

\begin{abstract}
This study aims to analyze the zakat and economic development of Bangka Belitung towards Sustainable Development Goals (SDGs) 2030. This program is agreed by various countries in the United Nations (UN) forum. There are 17 targets to be achieved in this program, which is the first target and the eighth target of alleviating poverty in all its forms in all places; And promote the sustainability of sustainable and inclusive economic growth, full and productive employment opportunities, and decent work for all. Both targets can make every region encouraged to think about the right policies to achieve the target of Sustainable Development Goals (SDGs) 2030. The research method uses simultaneous equation model with Ordinary Least Square (OLS) because the variables studied are related to each other. The variables studied are zakat and economic development which is represented by income per capita, poverty, and unemployment. The results of this study indicate that the variable of zakat has a significant positive effect on the economic development variables, namely income per capita and unemployment in Bangka Belitung while the poverty variable has a negative effect.
\end{abstract}

Keywords: zakat, economic development, income per capita, poverty, unemployment, and sustainable development goals.

\section{A. INTRODUCTION}

Development is a process of change towards better conditions through a planned effort. Todaro \& Smith (2006) defines economic development as a multidimensional process, involving major changes, both to changes in economic structure, social change, poverty reduction, inequality and unemployment in the context of economic growth. Existing government policies for economic development. The policy can be encouraged in the Sustainable Development Goals (SDGs) 2030 program. This program is 
agreed by various countries in the United Nations (UN) forum. There are 17 targets to be achieved in this program, which is the first target and the eighth target of alleviating poverty in all its forms in all places; and promote the sustainability of sustainable and inclusive economic growth, full and productive employment opportunities, and decent work for all. Both targets can make every region encouraged to think about the right policies to achieve the target of Sustainable Development Goals (SDGs) 2030.

Zakat is one of the policies and obligations of Muslims who have been implemented but not yet optimized. Many Muslim economists now develop zakat as an instrument of economic development, in which zakat as a monetary instrument can contribute to economic development. This is stated in research conducted by Azam, Iqbal, and Tayyab (2014) that zakat has a significant contribution to economic development in an area. The management of zakat is handled by many actors such as zakat amil institutions. The management of philanthropy is handled by many actors, such as Badan Amil Zakat Nasional (BAZNAS), the civil society such as Amil Zakat Institute as Rumah zakat, Rumah wakaf and so forth which are usually located in each province or their respective regions. As in the province of Bangka Belitung Islands is now zakat funds managed by the Badan Amil Zakat Nasional (BAZNAS) Bangka Belitung.

Table 1.1

Collection and Distribution of Zakat Funds of Bangka Belitung Province

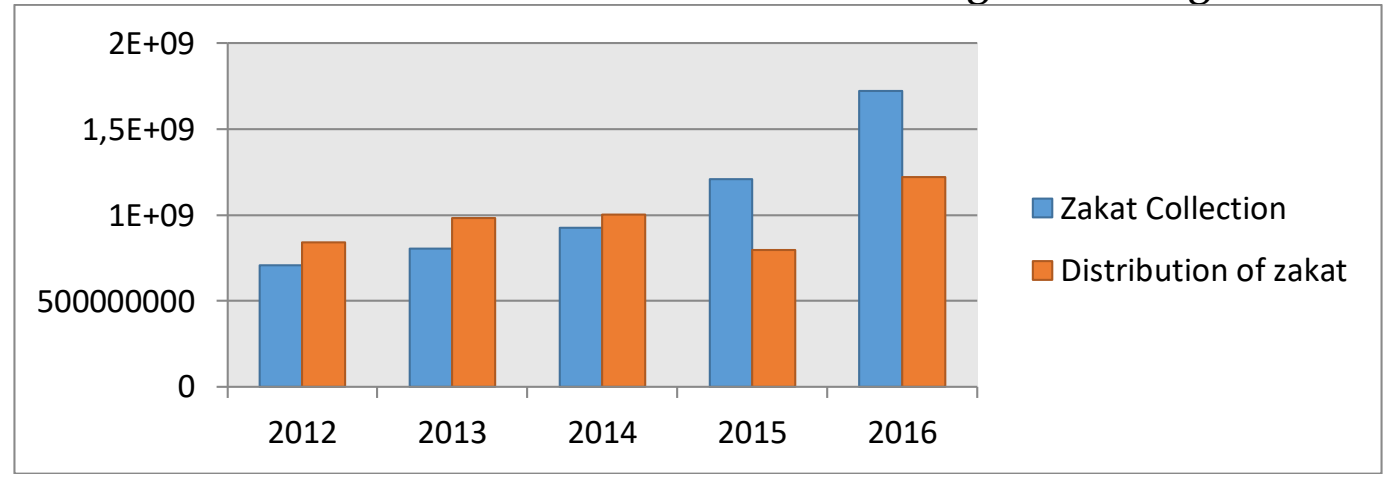

Source: BAZNAS BABEL, 2017 
It is seen that zakat receipts in Bangka Belitung Islands Province increased from year to year. This shows that more and more Muslims are aware of the importance of zakat. This revenue is expected to give a multiplier effect to the Indonesian economy. This is supported by research Arif (2009) stating that zakat will give effect to increase of income so that will increase public consumption and give effect multiplier to economic development. This study explains the zakat and economic development analysis of Bangka Belitung towards Sustainable Development Goals (SDGs) 2030.

Basically, this research is based on the framework of thinking that the collection and distribution of zakat funds in addition to aims to clean up the property and help the poor, also aims for economic development in an area. Based on the description, the specific questions of this research are:

1. How is the effect of the variable of zakat on income per capita variable in Province of Bangka Belitung Islands?

2. How is the effect of the variable of zakat on poverty variable in Bangka Belitung Islands Province?

3. How does the effect of the variable of zakat on unemployment variable in the Bangka Belitung Islands Province?

4. How is the influence variable of income per capita on the variable of zakat in Province of Bangka Belitung Islands?

5. How is the influence variable of income per capita on the variable of poverty in Bangka Belitung Islands Province?

6. How is the effect variable of income per capita on the variable of unemployment in Bangka Belitung Islands Province?

7. How is the effect variable of poverty on the variable of zakat in Bangka Belitung Islands Province?

8. How is the effect variable of poverty on the variable of income per capita in Bangka Belitung Islands Province? 
9. How does the effect variable of unemployment on the variable of zakat in Bangka Belitung Islands Province?

10. How is the effect variable of unemployment on the variable of income per capita in Bangka Belitung Islands Province?

\section{B. LITERATURE REVIEW}

Some of the previous research that became the reference in this research, among others: research conducted by Azam (2014) entitled Zakat and Economic Development: Micro and Macro Level Evidence from Pakistan. This study attempts to analyze the impact of zakat on economic development using micro and macro level data for Pakistan. The overall analysis shows that zakat has a positive impact on economic development in Pakistan. More specifically, micro evidence suggests that zakat significantly improves household welfare. Macro evidence also highlights that Zakat contributes significantly to economic growth in Pakistan. These findings have important implications for Pakistan.

Al Arif (2009) in his research stated that zakat will give effect to the increase of income so that will increase public consumption and give multiplier effect to economic development. Another study was conducted by Yusoff (2011) entitled Zakat Expenditure, School Enrollment, and Economic Growth in Malaysia. The main purpose of this study was to determine the impact of zakat spending and school enrollment on economic growth using panel data represented by fourteen states of Malaysia. The results of this study support the hypothesis that zakat spending and school enrollment are important determinants of economic growth in Malaysia. Zakat expenditure and student enrollment can significantly explain the variation in real output growth represented by real GDP growth. Therefore, it is recommended that all Muslim countries should increase the efficiency of zakat collection and spend wisely. 
Further research conducted by Tambunan (2016) under the title Investment Influence Analysis, Monetary and Zis Operation Against Economic Growth Indonesia. This research seeks to verify and explain the effects of investment, monetary operations and zakat on the Indonesian economy. The study found that about $97.2 \%$ of the conventional mutual fund, shariah mutual funds, FASBIS, and ZIS variables affect Indonesia's GDP from January 2013-December 2015, while 2.8\% is explained by other factors. Partially Conventional Mutual Funds, FASBIS, and ZIS have an effect on real GDP of Indonesia, while Islamic mutual fund has not been seen as real GDP of Indonesia.

Al Arif (2009) states that zakat gives a multiplier effect on economic development as well as Azam (2014) stated that zakat contributes significantly to economic development. Todaro \& Smith (2006) states that economic development involves changes such as reducing poverty, inequality, and unemployment in the context of economic growth. Economic development can not be separated from the variable income per capita, income per capita is a variable that represents the level of income society in a region. According to the theory of Umar bin Abdul Aziz, Caliph after Ali bin Abi Talib that zakat is very closely related to economic development. This is evidenced by his leadership zakat has managed to reduce poverty and unemployment up to $100 \%$ and increase income per capita. But when poverty and unemployment are overcome, the distribution of zakat funds decreases. The above theories state that zakat and economic development are interconnected. Figure 2.1 summarizes the framework underlying this study covering the variables used and previous research that became the reference to taking the variable. 
Figure 2.1 Framework Underlying

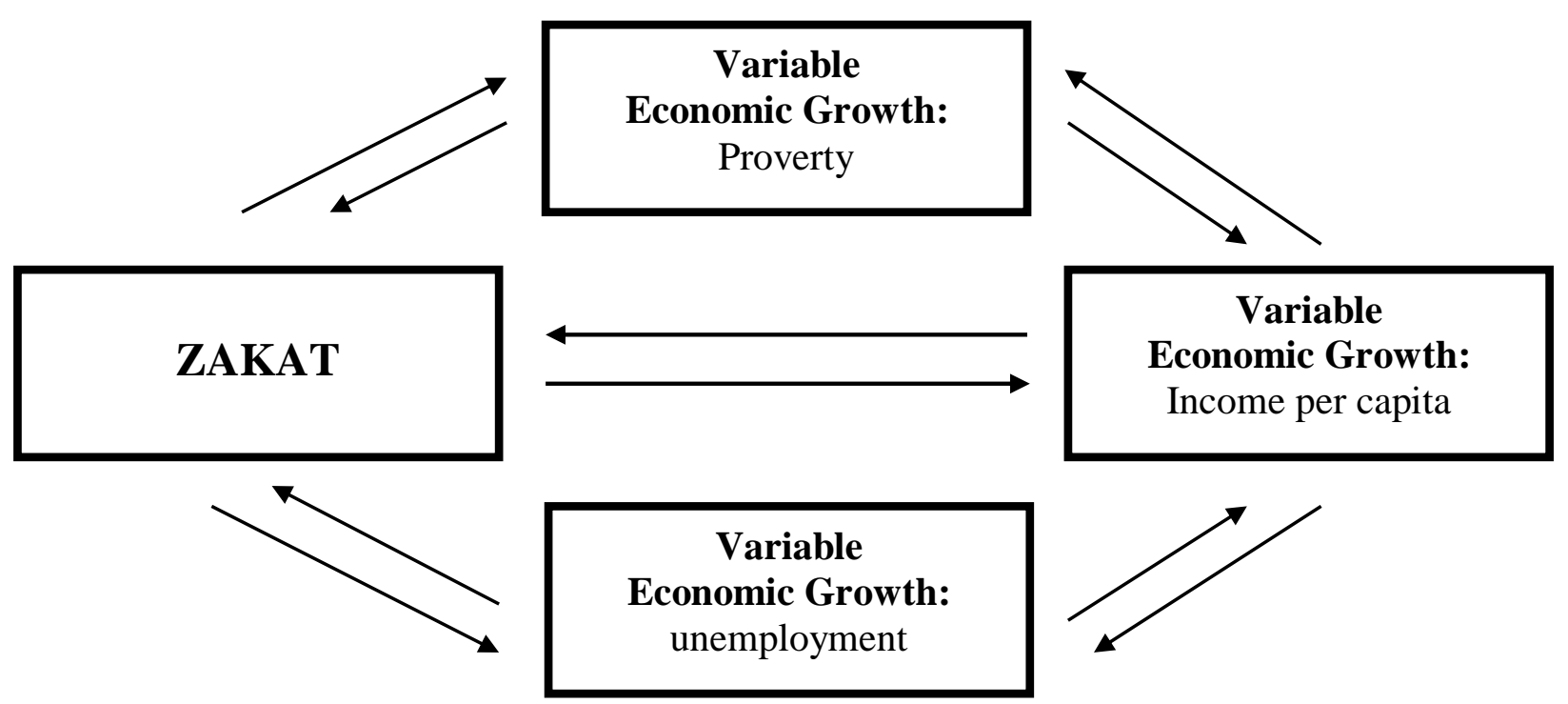

Source: Processed from various sources, 2017

Based on the study of theory and previous research, it can be formulated some hypotheses in this study are as follows:

H1: Zakat is capita has a positive income per capita

$\mathrm{H} 2$ : Zakat has a negative effect on poverty

H3: Zakat has a negative effect on unemployment

H4: Income per capita has a positive effect on zakat

H5: Income per capita has a negative effect on poverty

H6: Income per capita has a negative effect on unemployment

H7: Poverty has a positive effect on zakat

H8: Poverty has a negative effect on income per capita.

H9: Unemployment has a negative effect on zakat

H10: Unemployment has a negative effect on income per capita. 


\section{RESEARCH METHODOLOGY}

1. Scope of Study

Research on the analysis of zakat and economic development of Bangka Belitung is a verification research that aims to examine and test the theory empirically. Stages to be passed in this verification research are to test the hypothesis to explain the relationship between zakah variables and economic development variables in order to obtain information and meaning of research problems. Based on the relationship of variables formulated in the hypothesis, then will be analyzed the influence and relationship between some variables based on empirical data. Descriptions of the phenomenon of research problems are derived from zakat data and economic development such as poverty data, per capita income and unemployment data collected from secondary data sources. The object of this research is Bangka Belitung economy between 2005 and 2016.

2. Types and Data Sources

The type of data in this study is secondary data which is time series data (time series). The data collected comes from the Central Bureau of Statistics, National Amil Zakat Agency of Bangka Belitung Province and other credible data source information with the period from 2005 to 2016 which is used as a quantitative statistical analysis material so as to provide accurate information for decision making.

3. Data Collection Method

The method used to obtain data that exist in this research are: 1. Direct observation Attending the offices of the Central Bureau of Statistics, National Amil Zakat Agency of Bangka Belitung Islands Province and Bank Indonesia to obtain data on zakat, poverty, unemployment, and per capita income that is not presented in the website. 2. Indirect observation Conducted by opening and downloading data from the 
website for the object under study, so that information can be obtained related to this research, general description of zakat and economic development and growth. The sites used are:

a. http://babel.bps.go.id/

b. http://www.bi.go.id/id/publications/regionalregional/regional /babel/Default.aspx

c. http://baznasbabel.com/

4. Library study

Library study is the collection of data by studying and understanding books related to zakat and economic development, as well as discussions about poverty, unemployment, and income per capita obtained from various sources.

5. Operational Definition of Variables

Preparation of operational definition of the variable aims to clarify and facilitate understanding of the variables to be analyzed in this study, it is necessary to formulate the operational definition as follows:

a. Zakat $(Z)$ in this study the variable used is the ratio of zakat funds to zakat fund raising in the province of Bangka Belitung Islands in 2005 until 2016. Data were taken from the Amil Zakat Agency in the Province Islands of Bangka Belitung Islands.

b. The poverty rate $(K)$ is the percentage of population below the poverty line in the Bangka Belitung Islands province in 2005 to 2016 (in percentage units), data taken from the Central Bureau of Statistics of the Bangka Belitung Islands Province.

c. Unemployment rate $(\mathrm{P})$, in this research data used, is open unemployment data. Open unemployment is the percentage of the population in the labor force who are unemployed and looking for work in the province of Bangka Belitung Islands in 2005 to 2016 
measured in percentage units, data taken from the Central Bureau of Statistics of the Province of Bangka Belitung Islands and the published Regional Economic Review of Bangka Belitung By Bank Indonesia.

d. Per capita income (I) is the amount of regional income in the province of Bangka Belitung Islands divided by the number of people living in the province of Bangka Belitung Islands Province. Data were taken by the Central Bureau of Statistics of the Bangka Belitung Islands Province and the Regional Economic Review of Bangka Belitung published by Bank Indonesia from 2005 to 2016.

6. Data Analysis Method

Analyzing zakat and economic development of Bangka Belitung is formulated in simultaneous equation model because the variables studied are related to each other. The modeling in this analysis uses the system of equations, namely:

Zakat $=\beta_{10}+\beta_{11}$ Income per capita $+\beta_{12}$ Poverty $+\beta_{13}$ Mixed $+\varepsilon_{1}$

Income per capita $=\beta_{20}+\beta_{21}$ Zakat $+\beta_{22}$ Poverty $+\beta_{23}$ Unemployment $+\varepsilon_{2}$

Poverty $=\beta_{30}+\beta_{31}$ Zakat $+\beta_{32}$ Revenue per Capita $+\varepsilon_{3}$

Unemployment $=\beta_{40}+\beta_{41}$ Zakat $+\beta_{42}$ Revenue per Capita $+\varepsilon_{4}$

Endogenous variables consist of Zakat and Revenue per capita. Exogenous variables consist of poverty, unemployment, and per capita income. The method of analysis used is: (1) Descriptive analysis to know the characteristics of each variable. (2) Estimation of parameters using Ordinary Least Square (OLS). 


\section{RESULT AND DISCUSSION}

\section{Data Analysis}

a. Simultaneous Identification Test

The problem of identification in the simultaneous equation is important to arrive at the process of parameter estimation and subsequent economic analysis. The problem of identification means that the estimation of the parameters of the structural equation can be obtained from the reduced form estimated coefficient. If this step can be solved it means that the equation can be identified and if the above step is impassable it means that the equation can't be identified. Identification problem is done because from the same set of data can be obtained the estimated coefficients of the function/model/different hypothesis. To find out whether an equation in a simultaneous equation can be identified or not testable can be reviewed through the method of testing the order condition which is a necessary condition and the rank condition which is sufficient condition. Order condition testing method is a necessary prerequisite to being able to identify a model of simultaneous equations. An equation is said to be identified when the equation satisfies the following conditions:

$$
\mathrm{K}-\mathrm{k} \quad \mathrm{m}-1
$$

Where:

$\mathrm{K}=$ Number of predetermined variables in the model.

$\mathrm{k}=$ Number of predetermined variables in the estimated equation. $m=$ Number of endogenous variables in the estimated equation. The provisions in the identification of an equation model are:

1) If $\mathrm{K}-\mathrm{k}>\mathrm{m}-1$ is called overidentified

2) If $\mathrm{K}-\mathrm{k}=\mathrm{m}-1$ is called just / exact identified

3) If $\mathrm{K}-\mathrm{k}<\mathrm{m}-1$ is called underidentified 
Table 4.1 Identification of Simultaneous Equations

\begin{tabular}{|c|c|c|c|c|c|c|c|}
\hline Equation & $\mathbf{K}$ & $\mathbf{K}$ & $\mathbf{M}$ & $\begin{array}{l}\text { (K- } \\
\text { k) }\end{array}$ & Ket & $(m-1)$ & Identification \\
\hline Zakat & 4 & 3 & 1 & 1 & $>$ & 0 & Overidentified \\
\hline $\begin{array}{l}\text { Income per } \\
\text { capita }\end{array}$ & 4 & 3 & 1 & 1 & $>$ & 0 & Overidentified \\
\hline Proverty & 4 & 2 & 2 & 2 & $>$ & 0 & Overidentified \\
\hline Unemployment & 4 & 2 & 2 & 2 & $>$ & 0 & Overidentified \\
\hline
\end{tabular}

Source: Data processed, 2017

From the formulation of simultaneous equation model above then tested the problem of identification to fulfill order condition and rank condition. The results of the identification test on the simultaneous equations as formulated above obtained the information as shown in Table 4.1. The function of equations in a model is said to be identified when the equation meets the overidentified or just/exact identifiable conditions. While the equation underidentified conditions can not be identified.

b. Test Data Normality

Before testing to get the conclusion, then the data obtained need to be tested normality. Normality test aims to determine whether the data is normally distributed or not. It is important to know related to the accuracy of the selection of statistical tests to be used.

Table 4.2 Normality Test Results

\begin{tabular}{|l|l|l|l|}
\hline Variable & Jarque-Bera & Probability & Explanation \\
\hline Zakat per & 1.167997 & 0.642323 & Normal \\
\hline $\begin{array}{l}\text { Income } \\
\text { capita }\end{array}$ & 0.885329 & 0.557664 & Normal \\
\hline
\end{tabular}




\begin{tabular}{|l|l|l|l|}
\hline Proverty & 4.552934 & 0.102646 & Normal \\
\hline Unemployment & 1.654434 & 0.437265 & Normal \\
\hline
\end{tabular}

Source: Results of Data Processing with Eviews 9, 2017

Based on the results of data processing using software program eviews 9 on all endogenous variables and exogenous member Jarque-Bera value is smaller than $X^{2}$ (9.48773). A greater probability value than the probability value a (0.05) explains that the data for all variables are normally distributed.

c. Classic Assumption Test

Classic assumption tests include autocorrelation tests, multicollinearity tests, and heteroscedasticity tests to obtain valid estimation results that meet the BLUE (best linear unbiased estimator) criteria. The results of the classical assumption test in the system of simultaneous equations on this research can be seen in table 4.3 .

Table 4.3 Classic assumption test

\begin{tabular}{|c|c|c|c|c|c|c|c|}
\hline \multirow[b]{2}{*}{ Equation } & \multicolumn{3}{|c|}{ Autocorrelation } & \multirow{2}{*}{$\begin{array}{l}\text { Multicolinearity } \\
\text { Based on } \\
\text { Correlogram }\end{array}$} & \multicolumn{3}{|c|}{ Heteroscedasticity } \\
\hline & $\mathrm{Obs}^{*} \mathbf{R}^{2}$ & $\chi^{2}$-tabel & Exp. & & Obs* $\mathbf{R}^{2}$ & $\begin{array}{c}\chi^{2}- \\
\text { tabel }\end{array}$ & Exp. \\
\hline Zakat & 4.40273 & 68.70951 & Free & $\begin{array}{c}\text { There is no } \\
\text { Multicollinearity }\end{array}$ & 2.607666 & $\begin{array}{c}68.709 \\
51\end{array}$ & Free \\
\hline $\begin{array}{c}\text { Income } \\
\text { per capita }\end{array}$ & 9.59559 & 68.70951 & Free & $\begin{array}{c}\text { There is no } \\
\text { Multicollinearity }\end{array}$ & 1.416635 & $\begin{array}{c}68.709 \\
51\end{array}$ & Free \\
\hline Proverty & 5.61153 & 69.95683 & Free & $\begin{array}{c}\text { There is no } \\
\text { Multicollinearity }\end{array}$ & 0.263473 & $\begin{array}{c}69.956 \\
83\end{array}$ & Free \\
\hline $\begin{array}{c}\text { Unemploy } \\
\text { ment }\end{array}$ & 9.47665 & 69.95683 & Free & $\begin{array}{c}\text { There is no } \\
\text { Multicollinearity }\end{array}$ & 0.624208 & $\begin{array}{c}69.956 \\
83\end{array}$ & Free \\
\hline
\end{tabular}

Source: Results of Data Processing with Eviews 9, 2017

d. Simultaneous Equations Estimation Analysis

After going through the process of econometric test then the next process in the system of simultaneous equations is to analyze the estimation results of structural equations. The estimation result 
from the simultaneous equation to analyze zakat and economic development of Bangka Belitung can be seen in table 4.4.

Table 4.4 Simultaneous Equations Estimation Analysis

\begin{tabular}{|c|c|c|c|c|c|c|}
\hline \multicolumn{6}{|c|}{ Regression Of Zakat Function Equation } & \multirow[b]{2}{*}{$\begin{array}{l}\text { F- } \\
\text { statistic }\end{array}$} \\
\hline Variable & coefficient & t-Statistic & Prob. & t-table $\alpha=5 \%$ & $\mathrm{R}^{2} \mathrm{Adj}$. & \\
\hline LogIncome percapita & -0.767533 & -2.193199 & 0.0077 & 1.68023 & -0.660507 & 2.922700 \\
\hline Logproverty & -1.100689 & -1.825581 & 0.0026 & & & \\
\hline Logunemployment & 0.264488 & 2.180416 & 0.0077 & & & \\
\hline C & 31.66127 & 5.504523 & 0.0004 & & & \\
\hline \multicolumn{7}{|c|}{ Regression Of Income percapita Function Equation } \\
\hline Variable & coefficient & t-Statistic & Prob. & $\mathrm{t}$-table $\alpha=5 \%$ & $\mathrm{R}^{2} \mathrm{Adj}$. & $\begin{array}{l}\text { F- } \\
\text { statistic }\end{array}$ \\
\hline Logzakat & -0.110414 & -1.930199 & 0.0007 & 1.68023 & 0.774322 & 54.75366 \\
\hline Logproverty & -0.175010 & -9.094514 & 0.0001 & & & \\
\hline Logunemployment & 0.326360 & 12.57347 & 0.0000 & & & \\
\hline C & 15.69221 & 49.01940 & 0.0000 & & & \\
\hline \multicolumn{7}{|c|}{ Regression Of Income percapita Function Equation } \\
\hline Variable & coefficient & t-Statistic & Prob. & $\mathrm{t}$-table $\alpha=5 \%$ & $\mathrm{R}^{2}$ Adj. & $\begin{array}{l}\text { F- } \\
\text { statistic }\end{array}$ \\
\hline Logzakat & -0.971297 & -2.901029 & 0.0011 & 1.67943 & -0.612634 & 9.706801 \\
\hline Logincome percapita & 0.654523 & 1.966633 & 0.0002 & & & \\
\hline C & 9.608310 & 7.666270 & 0.0000 & & & \multirow{4}{*}{$\begin{array}{l}\text { F- } \\
\text { statistic } \\
83.94804\end{array}$} \\
\hline \multicolumn{6}{|c|}{ Regression of the Unemployment Function Equation } & \\
\hline Variable & coefficient & t-Statistic & Prob. & $\mathrm{t}$-table $\alpha=5 \%$ & $\mathrm{R}^{2} \mathrm{Adj}$. & \\
\hline Logzakat & 0.245277 & 12.159255 & 0.0002 & 1.67943 & 0.779235 & \\
\hline Logincome percapita & 2.420074 & 12.95736 & 0.0000 & & & \\
\hline C & -37.55547 & -12.35597 & 0.0000 & & & \\
\hline
\end{tabular}

Source: Results of Data Processing with Eviews 9, 2017

2. Zakat Analysis of Bangka Belitung

Zakat function equation model in this study include economic development variables, namely income variables per capita, poverty variables, and unemployment variables. The per capita income variable is included in the research model because per capita income is one of the determinants of government economic decision making and as a standard of living for a country. Variables of poverty and unemployment are two variables that have a big effect on the economic development of a country.

Poverty is a multifaceted, multidimensional, and integrated phenomenon. Poor living does not just mean living in conditions of lack of clothing, food, and boards. Living in poverty often also means 
low access to a wide variety of resources and productive assets that are essential to obtain the most basic means of living, such as information, science, technology, and capital. Moreover, living in poverty often also means living in alienation, low access to power, and therefore narrow and stuffy life choices. While unemployment is often a problem in the economy because with the unemployment, productivity and income society will be reduced so it can cause poverty and other problems.

The empirical findings in this study indicate that the value of regression coefficient of the variable of income per capita is -0.767533 with t-statistic value of $-2.193199>\mathrm{t}$-table 1.68023 on a (level of significance) $5 \%$ with the degree of freedom $n-k$. This shows that changes in income per capita have a negative and significant effect on zakat change in Bangka Belitung. The value of regression coefficient variable per capita income of -0.767533 means that each per capita income increase of 1 rupiah will reduce the distribution of zakat amounted to 0.767533 rupiahs. This empirical finding indicates that when per capita income rises will reduce the people who receive the zakat so that the distribution of zakat funds decreases. This means that the greater per capita income in Bangka Belitung will reduce the number of mustahiq in Bangka Belitung.

While the value of regression coefficient of poverty variable equal to 1.100689 with t-statistic value $-1.825581>$ t-table 1.68023 at a (level of significance) $5 \%$ with the degree of freedom (degree of freedom) n-k. This shows that the change of poverty variable has a negative and significant effect on the change of zakat variable in Bangka Belitung. The value of poverty variable regression coefficient of -1.100689 means that any increase in poverty of $1 \%$ will decrease the distribution of zakat by $1.1 \%$. This empirical finding proves that when poverty 
increases in Bangka Belitung will decrease zakat funds, it is due to the decline of the people who pay zakat so that zakat funds decreased and distribution decreased.

While the value of regression coefficient of unemployment variable equal to 0.264488 with t-statistic value $2.180416>$ t-table 1.68023 on a (level of significance) $5 \%$ with the degree of freedom (degree of freedom) $n-k$. This shows that the change of unemployment variable has the positive and significant effect to zakat variable in Bangka Belitung. The value of regression coefficient of unemployment variable is 0.264488 means that any increase of unemployment variable of $1 \%$ will raise the variable of zakat by $0.27 \%$. This empirical finding suggests that increasing unemployment in Bangka Belitung will increase the distribution of zakat funds in Bangka Belitung this proves that unemployment can increase social costs. As for the meaning of social costs is the cost incurred from the impact of unemployment. For example, costs incurred on the impact of crime committed by unemployment.

The value of the adjusted coefficient of determination (R2 Adjusted) of 0.660507 means the ability of independent variables in explaining the change in the value of the dependent variable of $66.05 \%$ while the rest is influenced by other factors outside the model of this study. While the overall correlation coefficient (F-statistic) is $2.922700>$ of the Ftable of 2.58 with a (level of significance) $5 \%$ with the degree of freedom $(\mathrm{k}=3)$ and denominator $(\mathrm{n}-\mathrm{k}=44)$ Shows that together all independent variables in the model affect the dependent variable.

3. Economic Development Analysis of Bangka Belitung

This research uses three equation model in analyzing economic development in Bangka Belitung that is a model of income per capita equation, a model of poverty equation, and model of unemployment 
equation. In theory, the economic development of independent and dependent variables that influence each other, then in this research use three equation model which independent variable in one equation can become dependent variable on other equation.

a. Equation of income per capita Model

The model of income per capita equation in research using three independent variables, namely variable of zakat, poverty variable, and unemployment variable. The empirical findings in this study indicate that the value of zakat variable regression coefficient is 0.110414 with t-statistic value $-1.930199>$ t-table 1.68023 at 5\% level of significance with a degree of freedom n-k. This shows that the change of zakat variable has a negative and significant effect on per capita income variable in Bangka Belitung. The value of zakat variable regression coefficient of -0.110414 means that every increase of zakah variables by $1 \%$ will decrease variable income per capita of $0.11 \%$. These empirical findings prove that in Bangka Belitung, the distribution of zakat funds does not increase the income per capita, this is because the pattern of distribution of zakat funds in Bangka Belitung still tend to be consumptive. The pattern of distributing consumptive zakat funds is only for the fulfillment of a momentary need, if the disbursed zakat funds are channeled for productive things then in the long term it will increase the income of the mustahiq which will eventually increase the income per capita of Bangka Belitung.

The second variable in the per capita income equation model is the poverty variable which has the coefficient value of -0.175010 with the value of t-statistic $-9.945144>$ t-table 1.68023 at a (level of significance) $5 \%$ with a degree of freedom $n-k$. This shows that the change of poverty variable has a negative and significant effect on 
the variable income per capita in Bangka Belitung. Value of regression coefficient of poverty variable equal to -0.175010 means that every increase of poverty variable equal to $1 \%$ will decrease variable of income per capita equal to $0,17 \%$. The empirical findings in this study are consistent with theories that explain the negative correlation between the magnitude of poverty to income per capita. The higher the poverty will decrease the amount of income per capita in Bangka Belitung.

While the unemployment variable in the equation model of income per capita has a coefficient value of 0.326360 with $t$ statistics of $12.57347>$ t-table 1.68023 on a (level of significance) $5 \%$ with a degree of freedom (n-k). This indicates that the change of unemployment variable has the positive and significant effect on variable income per capita in Bangka Belitung. The value of the regression coefficient of unemployment variables of 0.326360 means that each unemployment increase of $1 \%$ will increase percapita income by $0.33 \%$. This empirical finding is in contrast to economic theory in general. The existence of unemployment can affect the decline in economic activity or transactions. Public purchasing power may decrease and affect demand for goods, and services. Economic growth and per capita income will decrease. Bangka Belitung is one of the areas of interest to the public from outside the region, it can be said that the increase in per capita income in Bangka Belitung is caused by the income that comes from the increasing demand for goods and services coming from communities outside Bangka Belitung. The value of an adjusted coefficient of determination (R2 Adjusted) of 0.774322 means the ability of independent variables such as zakat, poverty, and unemployment in explaining changes in the value of the 
dependent variable of $77.43 \%$ while the rest is influenced by other factors outside the model of this study. While the overall correlation coefficient (F-statistic) is 54.75366> of the F-table of 2.58 with a (level of significance) $5 \%$ with a degree of freedom $(\mathrm{k}=3)$ and denominator $(\mathrm{n}-\mathrm{k}=44)$ Shows that together all independent variables in the model affect the dependent variable.

b. Model of Poverty Equation

The poverty equation model in the study used two independent variables, namely zakat variable, and variable income per capita. The empirical findings in this study indicate that the value of zakat variable regression coefficient is -0.971297 with t-statistic $2.901029>$ t-table 1.67943 on a (level of significance) 5\% with a degree of freedom $n-k$. This shows that the change of zakat variable has a negative and significant effect on poverty variable in Bangka Belitung. The value of zakat variable regression coefficient of -0.971297 means that any increase of zakat variable by $1 \%$ will decrease the poverty variable by $0.97 \%$. These empirical findings prove that in Bangka Belitung the distribution of zakat funds has succeeded in influencing poverty with negative influence. This indicates when the distribution of zakat funds in Bangka Belitung increases than will reduce the level of poverty. The second variable in the poverty equation model is the variable income per capita which has a coefficient value of 0.654523 with the value of t-statistics $1.966633>\mathrm{t}$-table 1.67943 on a (level of significance) $5 \%$ with a degree of freedom (n-k degree). This shows that changes in variable income per capita have a positive and significant effect on poverty variable in Bangka Belitung. The value of poverty variable regression coefficient of 0.654523 means that each increase in per capita income variable of $1 \%$ will increase 
poverty by $0.65 \%$. These empirical findings prove that there is an income disparity among the population where as per-capita income increases, poverty increases. This proves that in Bangka Belitung there is an uneven distribution of income.

The value of the adjusted coefficient of determination (R2 Adjusted) of 0.612634 means the ability of independent variables namely zakat and per capita income in explaining changes in the value of the dependent variable of $61.26 \%$ while the rest is influenced by other factors outside the model of this study. The overall correlation coefficient (F-statistic) is $9.706801>$ of F-table of 2.42 with a (level of significance) $5 \%$ with a degree of freedom $(\mathrm{k}=$ 2) and denominator $(\mathrm{n}-\mathrm{k}=45)$ indicating That together all the independent variables in the model affect the dependent variable.

c. Model of Unemployment Equation

The model of unemployment equation in the study using two independent variables, namely variable of zakat and variable of income per capita. Empirical findings in this study indicate that the value of zakat variable regression coefficient is 0.245277 with $\mathrm{t}$ statistic value $12.59255>$ t-table 1.67943 on a (level of significance) $5 \%$ with a degree of freedom ( $\mathrm{n}-\mathrm{k}$ degree). This shows that the change of zakat variable has a positive and significant effect on unemployment variable in Bangka Belitung. The value of zakat variable regression coefficient of 0.245277 means that each increase of zakat variable of $1 \%$ will increase the unemployment variable by $0.25 \%$. These empirical findings prove that in Bangka Belitung the distribution of zakat funds has not been able to create employment so that when increased zakat can't reduce unemployment in Bangka Belitung. 
The second variable in the model of unemployment equation is the variable of income per capita which has the coefficient value of 2.420074 with the t-statistic value $12.95736>\mathrm{t}$-table 1.67943 on a (level of significance) $5 \%$ with a degree of freedom (degree of freedom) n-k. This shows that changes in a variable of income per capita have a positive and significant effect on unemployment variable in Bangka Belitung. The value of regression coefficient of the variable of income per capita equal to 2.420074 means every increase of variable of income per capita equal to $1 \%$ will increase unemployment equal to $2.42 \%$. The empirical findings in this study indicate that in the province of Bangka Belitung Islands the number of the gross regional domestic product is controlled only by a small part of the people of Bangka Belitung so that when unemployment increases, per capita income will increase. This indicates an increase in the gross regional domestic product in Bangka Belitung is not accompanied by an increase in employment. If analyzed from the calculation of gross regional domestic income in the production approach, it can be concluded that GDP growth in Bangka Belitung is caused by the price of goods that continue to rise but not balanced with the increase in income society.

The value of the adjusted coefficient of determination (R2 Adjusted) of 0.779235 means the ability of independent variables namely zakat and income per capita in explaining the change in the value of the dependent variable of $77.92 \%$ while the rest is influenced by other factors outside the model of this study. While the overall correlation coefficient (F-statistic) is 83.94804> of Ftable of 2.42 with a (level of significance) 5\% with a degree of freedom $(\mathrm{k}=2)$ and denominator $(\mathrm{n}-\mathrm{k}=45)$ Shows that together 
all independent variables in the model affect the dependent variable.

4. Analysis of Zakat and Economic Development of Bangka Belitung Towards Sustainable Development Goals 2030.

Distribution of zakat in Bangka Belitung while still using the pattern of distributing consumptive zakat, consumptive zakat is zakat given to 8 asnaf to meet daily needs. Consumptive zakat is less helpful for long-term needs. This is because consumptive zakat only meets the daily needs and will run out without producing or just for the short term. Therefore, it is also a necessary pattern of zakat education that is zakat productive to the mustahiq.

Zakat can be utilized for productive efforts in the handling of the poor and improving the quality of the ummah if the basic necessities have been fulfilled. Zakat productive give a positive impact on development, economic growth, and welfare of the ummah if optimally. Zakat productive is very important in building a productive and innovative society in building a prosperous nation's economy. Zakat productive can be used as a poverty alleviation program by way of distribution of zakat in the form of business capital, business tools, skills training, and business guidance. The positive impact of productive zakat for the mustahiq that can live independently so he no longer needs to receive zakat when the economy has been established. When the mustahiq already have an established economy, then it will create new jobs and unemployment resolved.

Therefore, the zakat distribution paradigm of consumptive orientation should be transformed into productive orientation, so that poverty can be more effectively handled because zakat can be used as business capital to transform the dhuafa towards more independent and 
prosperous. The management of productive zakat must be understood by all people, especially muzaki, amil, and mustahiq. Zakat should be managed by a trustworthy and trustworthy amil zakat institution. When Islam is considered a welfare antithesis, for example in the case of terrorism or countries with the largest number of poverty and backwardness, the zakat movement with the perspective of SDGs will be seen as a contributor in solving the problems of the ummah. The World has established Sustainable Development Goals (SDGs) as one of the platforms of world development to improve human life. Once set on January 1, 2016, SDGs are then implemented in various countries that make the concept of SDGs a community development platform.

According to previous studies, the concept of zakat can be a solution in eradicating poverty, unemployment and becoming the solution of economic development in a country. However, according to empirical findings in this study, zakat has not succeeded in becoming a solution for Bangka Belitung to achieve sustainable development targets agreed by the member states of the United Nations (UN) namely Sustainable Development Goals.

In addition to government involvement, all countries that adopt the concept of SDGs, involve components in the society of Corporations, Civil Society and Philanthropy. Indonesia has set the four development platforms to be the pillar of the realization of SDGs in Indonesia that should be done also in the province of Bangka Belitung Islands. The zakat institution in the Bangka Belitung Islands Province can be the motor of the zakat movement in Bangka Belitung, looking at the SDGs as a tool to realize Indonesia's progress in achieving the target of Sustainable Development Goals (SDGs) in 2030. 


\section{E. CONCLUSIONS AND RECOMENDATIONS}

1. Conclusions

The conclusion of research result about zakat and economic development in Bangka Belitung towards Sustainable Development Goals as follows:

a. In the model of zakat equation, the value of the adjusted coefficient of determination (R2 Adjusted) of 0.660507 means the ability of independent variables of income per capita, poverty and unemployment in explaining the change in the value of a dependent variable of $66.05 \%$ while the rest influenced by other factors outside this research model. While the overall correlation coefficient (F-statistic) is $2.922700>$ of the F-table of 2.58 with a (level of significance) $5 \%$ with a degree of freedom $(\mathrm{k}=3)$ and denominator $(\mathrm{n}-\mathrm{k}=44)$ Shows that together all independent variables in the model affect the dependent variable.

b. In the equation of income per capita value of the adjusted coefficient of determination (R2 Adjusted) of 0.774322 means the ability of independent variables such as zakat, poverty, and unemployment in explaining changes in the value of the dependent variable of $77.43 \%$ while the rest influenced by other factors outside the research model this. While the overall correlation coefficient (Fstatistic) is $54.75366>$ of the F-table of 2.58 with a (level of significance) $5 \%$ with a degree of freedom $(k=3)$ and denominator $(\mathrm{n}-\mathrm{k}=44)$ Shows that together all independent variables in the model affect the dependent variable.

c. In the poverty equation the value of the adjusted coefficient of determination (R2 Adjusted) of 0.612634 means the ability of independent variables namely zakat and income per capita in explaining the change in the value of the dependent variable of 
$61.26 \%$ while the rest influenced by other factors outside the model of this study. The overall correlation coefficient (F-statistic) is $9.706801>$ of F-table of 2.42 with a (level of significance) $5 \%$ with a degree of freedom $(k=2)$ and denominator $(n-k=45)$ indicating That together all the independent variables in the model affect the dependent variable.

d. In the unemployment equation the adjusted coefficient of determination (R2 Adjusted) of 0.779235 means the ability of independent variables namely zakat and income per capita in explaining the change in the value of the dependent variable of $77.92 \%$ while the rest influenced by other factors outside the model of this study. While the overall correlation coefficient (F-statistic) is $83.94804>$ of F-table of 2.42 with a (level of significance) $5 \%$ with a degree of freedom $(k=2)$ and denominator $(n-k=45)$ Shows that together all independent variables in the model affect the dependent variable.

e. Distribution of zakat funds in Bangka Belitung while still using the pattern of distributing consumptive zakat, consumptive zakat is zakat given to 8 asnaf to meet daily needs. Consumptive zakat is less helpful for long-term needs. This is because consumptive zakat only meets the daily needs and will run out without producing or just for the short term. If this pattern continues, it will impact failure in economic development and failure to achieve the target of Sustainable Development Goals 2030.

2. Recommendations

Recommendations from the result of this research that zakat institution in Bangka Belitung have to change the pattern of distribution of zakat from consumptive become productive. Zakat productive can be used as a poverty alleviation program by distributing zakat in the form of 
business capital, business tools, skill training, and business guidance to create economic development and achievement of Sustainable Development Goals 2030 targets.

The achievement of the target of Sustainable Development Goals 2030 in Bangka Belitung should be done by involving the government and components in the society, namely the Corporations, Civil Society and Philanthropy such as Indonesia which has set the four development platforms to be the pillar of realization of SDGs in Indonesia by 2030. 
Eka Fitriyanti

\section{REFERENCES}

Al Arif, M. Nur Rianto. 2009. Efek Multiplier Zakat Terhadap Pendapatan di Propinsi DKI Jakarta. Jurnal Al-Iqtishad FSH UIN Syarif Hidayatullah Jakarta, Vol. 1, No. 1

Adisasmita. H. R. 2005. Dasar-dasar Ekonomi Wilayah. Jakarta: Graha Ilmu.

Ali, Muhammad Daud. 1998. Sistem Ekonomi Zakat dan Wakaf. Jakarta: UI Press

Azam, Muhammad. Dkk. 2014. Zakat and Economic Development: Micro and Macro Level Evidence from Pakistan. Bulletin of Business and Economics, $3(2), 85-95$.

Boediono. 1999. Teori Pertumbuhan Ekonomi. Yogyakarta: BPFE.

Departemen Agama RI, 1976. Al-Quran dan Terjemahannya, Yayasan Penyelenggara Penterjemah Al-Quran, Jakarta : PT Bumi Restu.

DREI (Dewan Redaksi Ensiklopedi Islam). 1993. Ensiklopedi Islam, Jakarta: PT. Ichtiar Baru

Ghozali, Imam. 2011. Aplikasi Analisis Multivariate Dengan Program SPSS. Semarang: Badan Penerbit Universitas Diponegoro.

Gujarati. 2012. Dasar-Dasar Ekonometrika. Salemba Empat, Jakarta.

Hafidhuddin, Didin. 2002. Zakat dalam Perekonomian Modern, Jakarta : Gema Insani.

Irawan dan Suparmoko. 2002. Ekonomi Pembangunan. Yogyakarta: BPFE.

Jhingan. M. L. 2000. Ekonomi Perencanaan dan Pembangunan. Edisi Kesembilan. Jakarta: PT. Raja Grafindo Persada.

Kuncoro, Mudrajad. 2004. Otonomi \& Pembangunan Daerah, Reformasi, Perencanaan, dtrategi, dan Peluang, Jakarta: Erlangga.

Muhammad Daud Ali, Habibah Daud Ali. 1995. Lembaga-lembaga Islam di Indonesia, Jakarta: Raja Grafindo Persada.

Munawir, Ahmad Warson. 1997. Kamus Al Munawir Arab-Indonesia Terlengkap, Surabaya: Pustaka Progresif, 1997. 
Qordhawi, Yusuf. 2002. Figh Zakat, Terj. Salman Harun, et.al., Jakarta: Litera Antar Nusa, Cet.6.

Rahman, Fazlur. 1996. Economic Doktrines of Islam. Terj Suroyo Nastangin "Doktrin Ekonomi Islam", Yogyakarta: Dana Bhakti Wakaf.

Ridwan, Muhammad. 2004. Manajemen Baitul Maal wa Tamwil, Yogyakarta: UII Press, 2004.

Sarea, Adel. Dr. 2012. Zakat as a Benchmark to Evaluate Economic Growth: An Alternative Approach. International Journal of Business and Social Science Vol. 3 No. 18

Sarsiti, Rakiman. 2012. Pengaruh Pendapatan Perkapita Dan Jumlah Wajib Pajak Terhadap Penerimaan Pajak Penghasilan Di Kabupaten Sukoharjo Periode 20022010. Working Paper. Sukoharjo.

Sukirno, Sadono. 1996. Pengantar Teori Makro Ekonomi. Cetakan Keenam. Jakarta: PT Raja Grafindo Persada.

Suliyanto. 2011. Ekonometrika Terapan: Teori dan Aplikasi dengan SPSS. Yogyakarta: ANDI.

Suryana. 2000. Teori-teori Pertumbuhan Ekonomi. Ekonomi Pembangunan: Teori, Masalah, dan Kebijakan. Yogyakarta: UPP AMP YKPN.

Tambunan, Khairina. 2016. Analisis Pengaruh Investasi, Operasi Moneter Dan Zis Terhadap Pertumbuhan Ekonomi Indonesia. At-Tawassuth, Vol. 1, No. 1, 2016: 73-94

Todaro, Michel. 2010. Pembangunan Ekonomi didunia Ketiga Edisi ke Tujuh. Jakarta: Balai Aksara.

Todaro, Michael P dan Smith, Stephen C. 2006. Pembangunan Ekonomi, Jakarta: Erlangga

Undang-Undang No. 38 Tahun 1999.

Untoro, Djoko. 2010. Buku pintar. Jakarta; Wahyu Media.

Winarno, Wing Wahyu. 2007. Analisis Ekonometrika dan Statistika dengan Eviews, UPP STIM YKPN, Yogyakarta. 
Eka Fitriyanti

Yusoff, B. Mohammed. 2011. Zakat Expenditure, School Enrollment, and Economic Growth in Malaysia. International Journal of Business and Social Science Vol. 2 No. 6; April 2011 